Cómo citar este artículo en APA: Comanducci, C. (2022). Faceless Violence and the Gestural Commons: The Ethics and Politics of Destitution and Support in Butler, Agamben, and Federici. Analecta Política, 12(22), 1-32. doi: http://dx.doi. org/10.18566/apolit. v12n22.a3

Fecha de recepción: 24.08.2021

Fecha de aceptación: 10.12.2021

\section{Faceless Violence and the Gestural Commons: The Ethics and Politics of Destitution and Support in Butler, Agamben, and Federici}

La violencia sin rostro y los comunes gestuales: la ética y la política de la destitución y el apoyo en Butler, Agamben y Federici

\section{CARLO COMANDUCCI}

PhD Film Theory

Master in Film Studies and in Italian Literature and Culture

Vistula University, Warsaw, Poland Orcid: https://orcid.org/0000-0001-5042-2269

c.wayward@zoho.com 


\section{3.) Abstract \\ This article brings to bear different strands of critical theory on the issue of police violence and securitarian capitalism, with a focus on the current situation in France, discussing Judith Butler's argument for nonviolence in The Force of Nonviolence in relation to Jacques Rancière's distinction of politics and police, Giorgio Agamben's ideas of gesture and act, and Silvia Federici's understanding of primitive accumulation and reproductive commons. These authors, from their different perspectives, address how the questions of the distribution and the legitimation of violence involve forms of individuation that cut into a common dimension of relationality and interdepen- dency, systematically denying structural violence. On this basis, they understand the ethics and politics of nonviolence to be the matter of a common use of bodies: Butler, in the sense of an aggressive defence of those interrelational bonds that are formative of human subjects; Agamben, in the sense of a shift in our mode of thinking and doing from property and belonging to use and dwelling, as part of the destitution of the biopolitical and juridical capture of lives; Federici, as forms of mutual support organised in a struggle against the imposition of capitalist relations of production and reproduction. Moving from the question of the figuration of violence and the State's semantic monopoly on its attribution to that of police violence and its centrality in the current paradigm of government, the article connects the various epistemologies of subjectivity in Butler, Agamben, and Federici to the critique of techniques of individuation and structural forms of vulnerabilisation that are characteristic of the police State, proposing an anarchist perspective on nonviolence as part of a larger defence of reproductive and gestural commons.}

Keywords: Anarchy, Giorgio Agamben, Judith Butler, Commons, Destitutive power, Silvia Federici, Gesture, Police violence.

\section{Resumen}

Este artículo aporta diferentes líneas de teoría crítica sobre el tema de la violencia policial y el capitalismo securitario, con un enfoque en la situación actual en Francia, discutiendo el argumento de Judith Butler a favor de la noviolencia en The Force of Nonviolence ( $L a$ fuerza de la noviolencia) en relación con la distinción de política y policía de Jacques Rancière, las ideas de gesto y acto de Giorgio Agamben, y la comprensión de Silvia Federici de la acumulación primitiva y los bienes comunes reproductivos. Estos autores, desde sus diferentes perspectivas, abordan cómo las cuestiones de la distribución y la legitimación de la violencia implican formas de individualización que se cruzan en una dimensión común de relacionalidad e interdependencia, negando sistemáticamente la violencia estructural. Sobre esta base, entienden la ética y la política de la noviolencia 
como materia de un uso común de los organismos: Butler, en el sentido de una defensa agresiva de aquellos lazos interrelacionales que son formativos de los sujetos humanos; Agamben, en el sentido de un cambio en nuestro modo de pensar y hacer desde la propiedad y la pertenencia hasta el uso y la vivienda, como parte de la destitución de la captura biopolítica y jurídica de las vidas; Federici, como formas de apoyo mutuo organizadas en una lucha contra la imposición de las relaciones capitalistas de producción y reproducción. Pasando de la cuestión de la figuración de la violencia y el monopolio semántico del Estado sobre su atribución a la violencia policial y su centralidad en el paradigma de gobierno actual, el artículo conecta las diversas epistemologías de la subjetividad en Butler, Agamben y Federici a la crítica de técnicas de individualización y formas estructurales de vulneración propias del Estado policial, y propone una perspectiva anarquista de la noviolencia como parte de una defensa más amplia de los bienes comunes reproductivos y gestuales.

Palabras clave: Anarquía, Giorgio Agamben, Bienes comunes, Judith Butler, Silvia Federici, Gesto, Poder destituyente, Violencia policial.

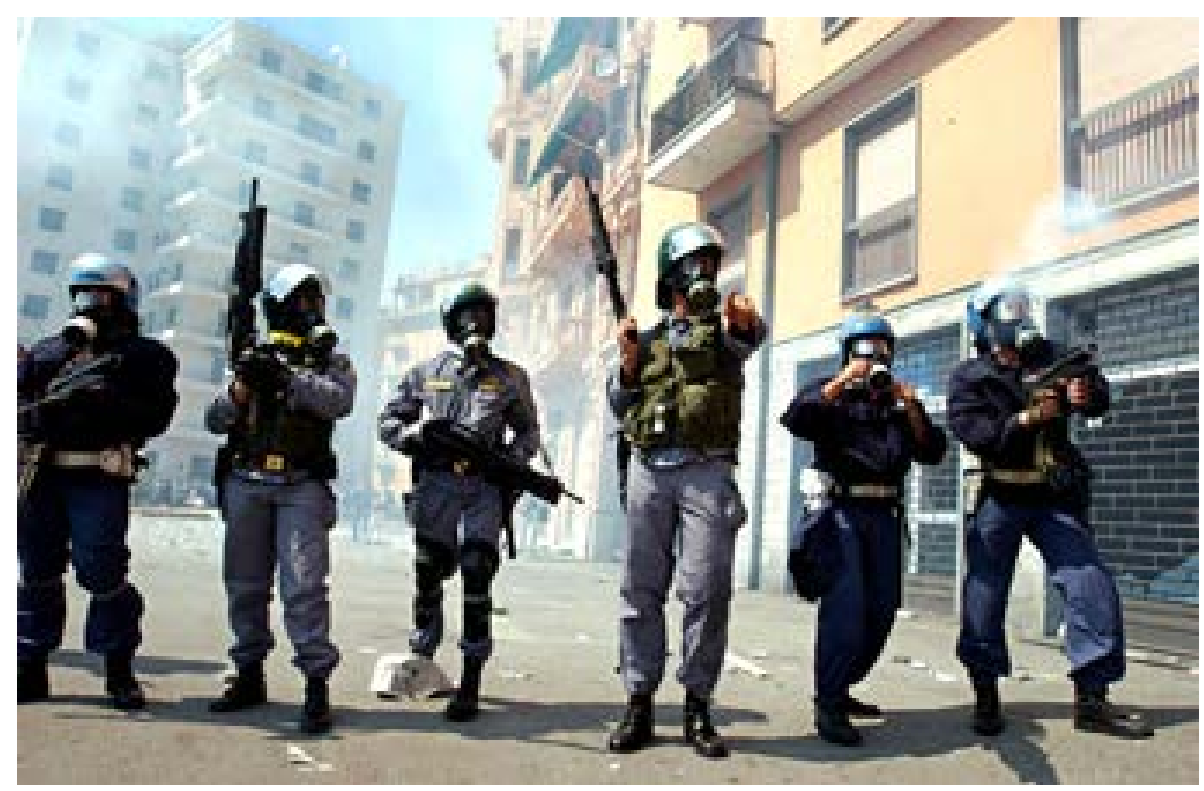

"We have read you some very sensible regulations, devised both for your safety and our pleasures - follow them blindly and be prepared for anything on our part if you irritate us with your poor conduct." Marquis de Sade, The 120 Days of Sodom. 


\section{Hobbes for Kids: The Figuration of Violence}

The 2016 Disney flick Zootopia (Howard and Moore, dirs. USA), all too comfortably and in a self-conscious way, evokes popularised Hobbesian tropes about the state of nature and the social contract. In the little school play the film begins with, and in which the "phantasmatic scene" (Butler, 2020, paragraph 2.81) concerning the foundation of the zootopian community is dramatised, the war of every one against every one has become the law of the jungle. Hobbes's commonwealth is turned into a matter of biological evolution transcending the predators' "uncontrollable biological urge to maim and maw" and the meekness and gregariousness of natural preys. This allows preys and predators to live in a harmonious, "civilised", community in which vulnerable animals will not need to fear their carnivorous peers, seemingly fulfilling the promise of a world in which animals will no longer be bound to their respective natures.

At the midpoint of the performance, the little actors in the recital uncover what they would like to do when they grow up in this liberated society: a sheep wants to be an astronaut, a leopard wants to hunt for tax exemptions, and the rabbit Judy -in order, we are told, to "make the world a better place"- wants to become a police officer.

Figure 1: "A police officer!"

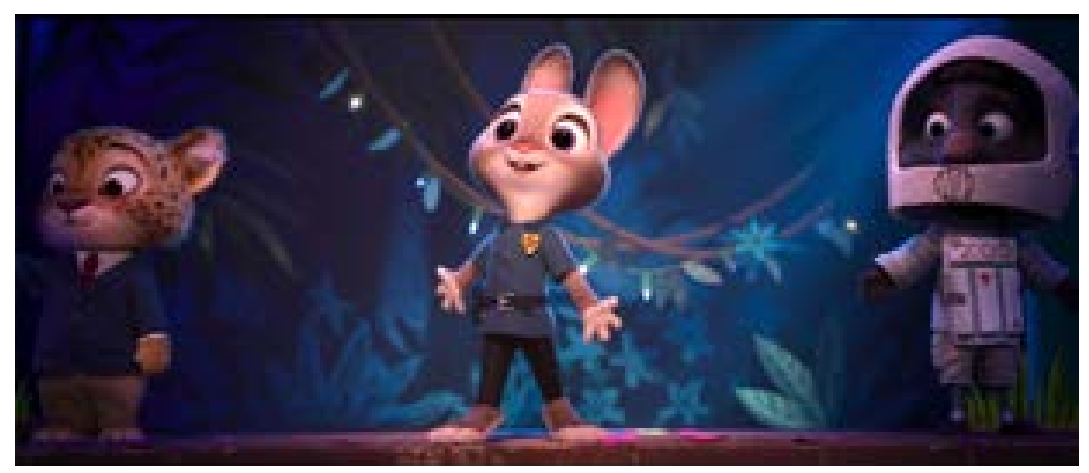

With its recasting of Hobbes's non-secular ideals in the language of biology and neoliberal self-affirmation, and with its explicit focus on the question of policing, 
Zootopia becomes relevant, on the one hand, to a reflection on the imbrication of law enforcement and the construction of social order in "securitarian capitalism" (Rigouste, 2011, pp. 298, 299) and as an example of the reach into popular culture of the hegemonic discourse on the legitimate use of violence by the State, on the other.

To be sure, the animation film flirts in a questionable way with the subversion of essential identities: a rabbit can prove to be something else than a fearful victim, but her fearlessness still acquires special value and is supposed to require special effort because she is born a rabbit, and a female rabbit at that. In the end, the neoliberal discourse on equality reinforces, rather than suspend, the idea that certain qualities are essentially and biologically given.

But besides the conspicuousness of its ideology, and beyond all the cuteness and furriness which are thrown at us, Zootopia's concern rests seriously with the relation between nature and law, violence and order. A relation to which it gives a particular spin, bringing it close to an apology of the police State. The bunny who dares to be a pig, indeed, reveals her vocation precisely at the moment in which, according to the Hobbesian scenario the children are rehearsing, the sovereign should appear on the stage. Blurring all lines between community and order, political delegation and obeisance to institutional force, what is supposed to embody the unity of the multitude turns out to be not a king or a president, but a police officer; not a delegate, but an enforcer.

Law enforcement is thus given as the foundational principle of the State and of the community, in a way that, though not far from Hobbes's theology of commandment, which already implied a confusion between the juridical sphere and that of force -"for the commands of the rulers, are the laws of the ruled [...]" (Hobbes, 2017, p. 115) - fits even more squarely the current convergence, emerging from the history of colonisation and taking the form of a global securitarian order at least starting from 2001, between the prerogatives of government and the operations of police within a permanent state of exception.

According to this paradigm of State power, governments increasingly recur to, and government increasingly consists in, the creation of lawless areas (zones de non-droit) in which the exercise of the law, the defence of the population, and the use of force cannot be easily distinguished. In prison camps like Guantanamo, at borders and in immigrant detention centres, in "hot neighbourhoods" (quartiers à risque or Zones Urbaines Sensibles) (Rigouste, 2011, p. 269), or even during political demonstrations, subjects who, by their actions, their simple presence, or 
their mere existence, are captured outside of the given order are treated as enemies of the State. In other words, they are subjected to an extra-legal violence that is always-already justified as the defence of legality itself. The modern State and its exacerbated forms in securitarian capitalism extend the logic of lawless areas to the nation and to the whole world as such, in what Agamben has described as a permanent state of exception that has become the rule (Agamben, 1998, pp. 9, 17, 19-20).

In his work on the securitarian paradigm of power in France, Mathieu Rigouste traces how the category of internal and external enemy become blurred in the context of the techniques of law enforcement and counterinsurgency emerging from the colonial State.

In a way, this very convergence is subsumed by an older, theological, category: that of the enemy of God. In Hobbes, those who do not acknowledge the commands nor stand in awe of the threats of God are banned beyond the sphere of rights and exposed not to punishment, but to a much more radical banishment and destruction:

"Those only therefore are supposed to belong to God's kingdom, who acknowledge him to be the governor of all things, and that he hath given his commands to men, and appointed punishments for the transgressors. The rest we must not call subjects, but enemies of God." (Hobbes 2017, p. 115)

The police State can be understood, from this perspective, as a secularisation of a "divine" economy of violence (see Agamben 2017, pp. 435-436, 376-377) -that is, of a relation between a constituted, providential, order and its enforcement; a relation that is given as unchangeable and, in itself, necessary and good. Police violence, in this sense, is justified on the basis of the providential, unquestionable, character of the State form and of capitalist relations of production, as well as of the naturalised forms of life that go with them (like the heteronormative categories of "man" and "woman").

In the gesture of Judy unveiling her desired form of life -at once literally her uniform and her dream- the film also ties the indistinction of sovereignty and police to the neoliberal discourse of disciplinary self-assertion: what in Hobbes is the moment of the subjection of one's will to the general will, which establishes the sovereign body, is presented as the moment of defiant self-realisation.

As Zootopia shows very clearly, the police officer becomes the main figure of contemporary biopower, where personal security and the integrity of the State 
are, forcibly, put in a zone of indistinction, and in which the minimal articulation necessary for social existence and bodily survival is given as one between the police and the policed. In the film, the figure of the vulnerable, very much "white" rabbit who decides to join the force corresponds to a polity which foregrounds an ideology of "post-species" harmony, all while arming itself to keep the predators' primal instincts in check (for a critique of Zootopia's racist discourse, see Faraci, 2016).

Figure 2: "Fox Away"

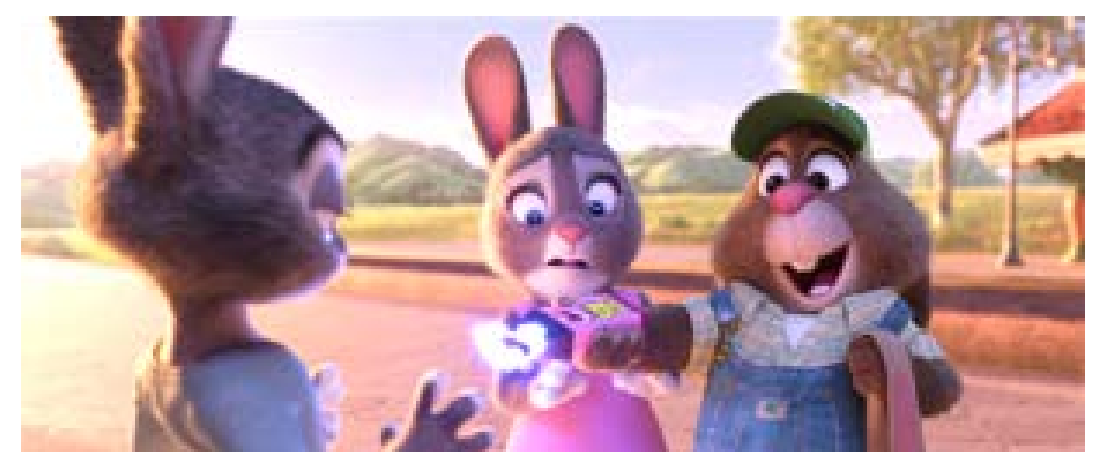

In another teeth-grinding moment, daddy rabbit insists on giving a "fox taser" to his daughter who is about to leave for the big city on her first assignment after graduating from the police academy. What is at stake here is not only the normalisation of armed violence and of the use of "less-lethal" force like electroshock weapons, but also a particular figuration and distribution of violence. The harm the taser causes, the use of which the relative UN Committee classified as a form of torture in 2007, disappears through the racist invocation of the violence of the city environment -"Zootopia is full [of predators] and foxes are the worst"- from which the police officer will have to defend herself.

What appears clearly through Zootopia is one of the initial problems addressed by Butler in The Force of Nonviolence, that of the discursive framing and figuration of violence.

"If one wants to make an argument in favor of nonviolence," Butler writes, "it will be necessary to understand and evaluate the ways that violence is figured and attributed within a field of discursive, social, and state power; the inversions that are tactically performed; and the phantasmatic character of the attribution itself. Further, 
we will have to undertake a critique of the schemes by which state violence justifies itself, and the relation of those justificatory schemes to the effort to maintain its monopoly on violence. That monopoly depends upon a naming practice, one that often dissimulates violence as legal coercion or externalizes its own violence onto its target, rediscovering it as the violence of the other." (Butler 2020, 2.50)

In this sense, the justification of violence is regularly structured around the discourse of self-defence, and vice-versa, as Elsa Dorlin argues (2019, p. 47), with distinctions being established between those who are entitled or not entitled to defend themselves or be defended, and those who are construed as threats instead. Thus, a fox with a weapon would immediately appear as a menace, while a rabbit with a weapon would evidently be engaged in self-defence -we see here the other function of essentialised identities in the film.

From the very onset, then, the question of violence -in particular, as we will see, as it further involves an articulation between structural violence and personal, visible, acts of violence- is caught in its performativity, that is, in practices of attribution and nomination, representation and figuration, spectacular framing and ideological disavowal.

Violence is always interpreted, attributed, distributed but, as Butler notes, is never just an interpretation. This is why it is possible to counter relativistic arguments and address not only how violence "appears within frameworks that are sometimes incommensurable or conflicting, and so it appears differently - or altogether fails to appear" (Butler, 2020, 2.61), but also how a structural and systemic imbalance exists in the power to attribute violence, which is used to justify state violence against those who oppose it.

"If a demonstration in support of freedom of expression, a demonstration that exercises that very freedom, is called 'violent,' that can only be because the power that misuses language that way seeks to secure its own monopoly on violence." (Ibid., 2.47)

For Butler, a dispute on the attribution and definition of violence underlies the articulation between the legitimate and the illegitimate use of force and commands a structurally unequal distribution of vulnerability, disposability, and grievability or value of lives. In this respect, the State, the media, and various other institutions, in a complex but significantly tightening mediatico-securitarian machine (machine médiatico-sécuritaire) (Rigouste, 2011, p. 230), can be seen to 
constitute and defend a semantic as well as a juridical and technical monopoly on violence (see Butler, 2020, 2.47).

In what is perhaps its strongest, this semantic monopoly on violence takes the form of silence as well as that of a prohibition to speak. As Emmanuel Macron intimated on the 7th of March 2019 in Gréoux-les-Bains, cynically, as part of the Great National Debate (Grand Débat National): "do not speak of repression, of police violence, these words are unacceptable under the rule of law [dans un état de droit]" (Le Monde, 2019). The legitimate use of violence, the statement implies, is a matter of definition; it depends first of all on a power over words: under the rule of law which the police is meant to defend, there is no such thing as police violence, and thus the wrong is displaced on the speech that names it.

When a chief of State speaks thus, we are not in the domain of arguments, really, but in that of performatives and of the power that is attached to positions of enunciation: operative, rather than political, power. Through disciplinary discourses, media manipulation, and this kind of systemic omertà, the State's code of silence, police violence extends its reach in the field of language and figuration, performances and gestures themselves.

In 2020, the French government proposed a bill (Loi Sécurité Globale) which included prohibiting the public diffusion of images of the faces, or any other element of identification, of police officers in the exercise of their functions. The law is feared to target the practice of militant reporting and the use of smartphones and cameras as forms of self-defence against police brutality. It clearly constitutes an attempt to increase the vulnerability of the potential victims of police violence (mostly refugees, immigrants, Blacks, Muslims, people from the banlieues, protesters, and militants) and to prevent accountability for both the personal actions of specific agents and the systemic use of the police by the French State. Indeed, it was and remains potentially dangerous to film and speak out against police violence in France today, even as the bill is still referred for review by the Constitutional Court. This kind of provision shows the State's attempt to maintain the monopoly over legitimate violence by exerting control over the nomination and the becoming-visible of single acts of violence. 
Figure 3: Man with a Moving Camera

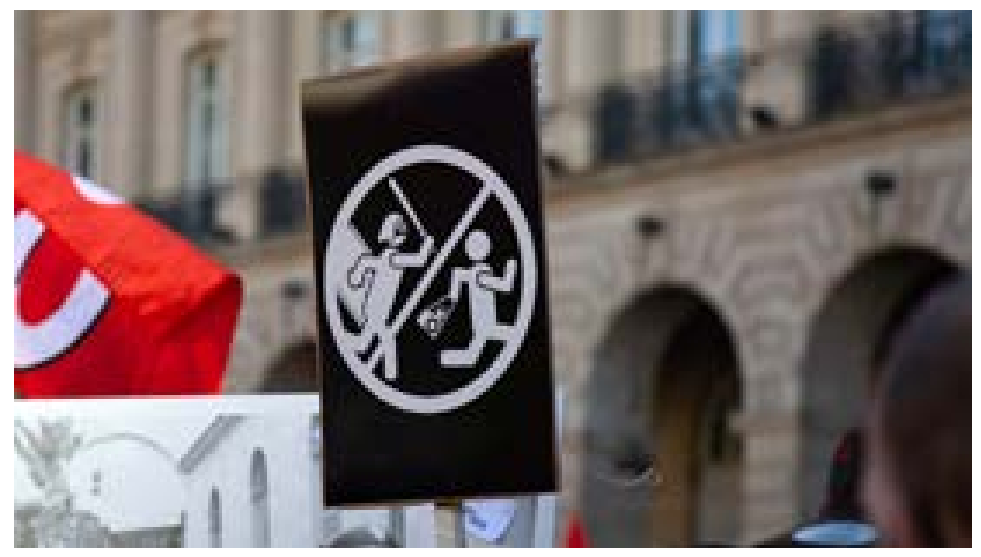

The counterpart of this prohibition to show and this interdiction to name police violence is the hypermediatisation and the framing of acts of protest as "violent", the casting of cultural others and troublemakers (casseurs) as a faceless, but extremely visible danger to the order and thus the existence of the nation. On the occasion of a speech on the 31st of December 2018, Macron, using dangerous nationalist identitarian rhetoric, had called the actions of the Gilets Jaunes "the negation of France" (Reuters, 2018). This construction of the internal enemy through ideology and police action, as Rigouste argues throughout L'Ennemi Intérieur, is rooted in the history of French colonial government and counterinsurgency doctrines developed during France's colonial wars and the brutal repression of the Algerian liberation.

At many levels, then, we see a continuity between the monopoly of legitimate violence and mediation, police violence and broader forms of structural violence and oppression, within a whole field of discourses, practices, and representations that has claims over the very consistency of our reality, of what can be said to exist. In this sense, even before it becomes illegal to show the image of a policeman's face, the violence that is at stake here is invisible: it does not appear (as such) and does not have a face you can relate to.

As Michel Foucault suggested and Jacques Rancière gave particular emphasis to $(1999$, p. 28$)$, "police" names a function that vastly exceeds the use and the actions of the police force and rather names a whole distribution of the sensible which, in its modality, is the opposite of politics. 


\begin{abstract}
"The police is thus first an order of bodies that defines the allocation of ways of doing, ways of being, and ways of saying, and sees that those bodies are assigned by name to a particular place and task; it is an order of the visible and the sayable that sees that a particular activity is visible and another is not, that this speech is understood as discourse and another as noise.” (Ibid., p. 29)
\end{abstract}

Rancière is right to stress the reductiveness of framing this broader dimension of police in terms of law enforcement alone. If we take Rancière's understanding of "police", the expression "police violence" can be used to name not just physical violent actions perpetrated by police officers in the exercise of their functions, but a broader dimension of violence, intimidation, and pressures, that relate to structural and systemic violence and belong to the legal, disciplinary, economic, discursive, and performative fields invested by the State.

It is also true, however, that in the exercise of violence by the police, from racial profiling to the deployment and use of tear gas and riot guns, a particular relation to the body appears that is at the centre of the question of power. In police violence, and especially in situations in which weapons are directed against the unarmed, some aspects of violence in its relation to government become more visible: namely, how violence addresses bodies in the place of subjects -how it has effects of subjectivation (see Fanon 1963, pp. 288-289) at the very time in which it denies the status of subjects to its targets. If a certain reading of Foucault would eclipse State violence behind the disciplinary relation between power and the body in modernity, this violence persists at the core of government precisely in the form of law enforcement and police violence, as the violence that turns the suffering body into a visible compliance to order.

Figure 4: "Voilà une classe qui se tient sage."

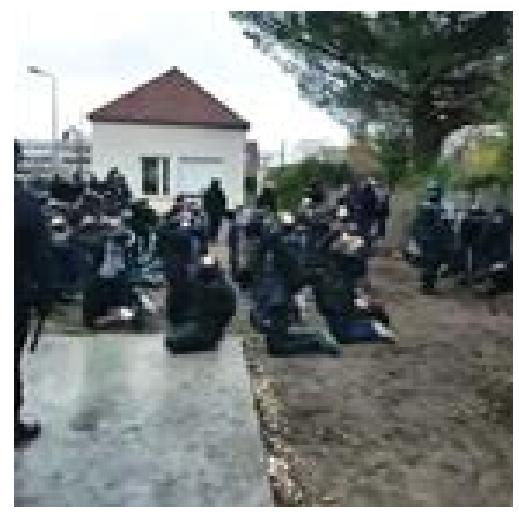


In a video taken by one police officer during the repression of a students' protest in Mantes-la-Jolie, a town in the periphery of Paris, on the 6th of December 2018, secondary school students are being held hands behind their heads kneeling. At one point, the officer comments: "Here's a class that is wellbehaved." With no different cynicism than Macron's, the teens are put in a zone of indistinction between being subject to force and consenting to (the social) order. In being forced to obey, they are not interpellated as speaking subjects, but they are nevertheless construed as the ideal body politic; hence, the title of David Dufresne's documentary on police violence that refers to the policeman's phrase, Un Pays Qui Se Tient Sage [A Well-Behaved Country] (France, 2020). Police violence, in this sense, is the moment in which the affirmation of legality becomes indistinguishable from the reflex of pain or the reaction to a physical threat, in which torture and terror are put in a zone of indistinction with consent.

When subjected to violence, the body is consigned to a state beyond dialogue and relationality; it is captured as speechless in the operation of commandment. Violence can be defined as a form of address that captures subjects outside of speech and, if we understand ethics after Emmanuel Levinas as a reaching toward speaking beings in a dialogue, it constitutes a mode of relation opposite to the ethical. From this perspective, law enforcement appears not, like we are told, as a special measure for the defence of the polity, but as the very paradigm of violence: as the operation that decides over the threshold between commandment and law. It is not violence in general, in fact, but the legitimate use of violence that corresponds to the production of bare life. ${ }^{1}$

There is an unbroken continuity between sovereign decisions over language, such as Macron's imperious negation, and forms of commandment that take the speechless body as their target, such as the techniques of intimidation and terror used by the police against "internal enemies" in France. Both are biopolitical, as both are bent on producing bare life: one denies the speech that denounces the violence which the other inflicts against a body treated as a thing without a name.

The kind of education to a certain understanding and distribution of violence, law enforcement, and self-defence, that we can find in a film like Zootopia appears

1 It is important to remember that bare life, for Agamben, is not an originary, pre-discursive, animal, body, but is always the product of the operations of power. In this sense, Agamben's understanding of biopolitics is coherent with Butler's discussion of the insistence of power in the very materialisation of bodies. See Judith Butler, Bodies that Matter: On the Discursive Limits of "Sex" (London: Routledge, 1993), xii. 
then as the image -in Guy Debord's sense, a commodity and a spectacular displacement- of what happens all too often in the world's Mantes-la-Jolie. Securitarian capitalism leaves us no alternative between the carrot and the stick: rather, we are supposed to buy the one and eat the other.

\section{Individuation: Butler and Agamben on violence beyond the blow}

One of the cornerstones of the current figuration of violence -bound at various points with its justification and legitimate use, with the idea of selfdefence, with sexism and patriarchy, and with the establishment of the extensive counterinsurgency programs that are characteristic of securitarian capitalism- is an articulation between structural violence and personal, visible and isolable, acts of violence.

Butler refers to these acts through the figure of the blow:

"the figure of the blow has tacitly organized some of the major debates on violence, suggesting that violence is something that happens between two parties in a heated encounter. Without disputing the violence of the physical blow, we can nevertheless insist that social structures or systems, including systemic racism, are violent." (Butler, 2020, 2.46)

The scene conjured by this figure functions as a paradigm or a conceptual metaphor that systematically downplays and invisibilises broader and more abstract forms of violence. On the contrary, these structures can be seen to affect bodies directly in ways that are violent and destructive, and, indirectly, they set the conditions in which acts of physical violence against certain subjects become possible, likely, unaccounted for, legitimate.

A significant effort, epistemological as well as practical, is made in order to individualise structural violence and deny its systemic valence. Techniques of individuation, indeed, at all levels, organise the distribution of the sensible in which legitimate and illegitimate forms of violence appear, "violence" is attributed, the right of self-defence is accorded or denied, and lives are exposed differentially to precarity and harm. 
Figure 5: "Police State."

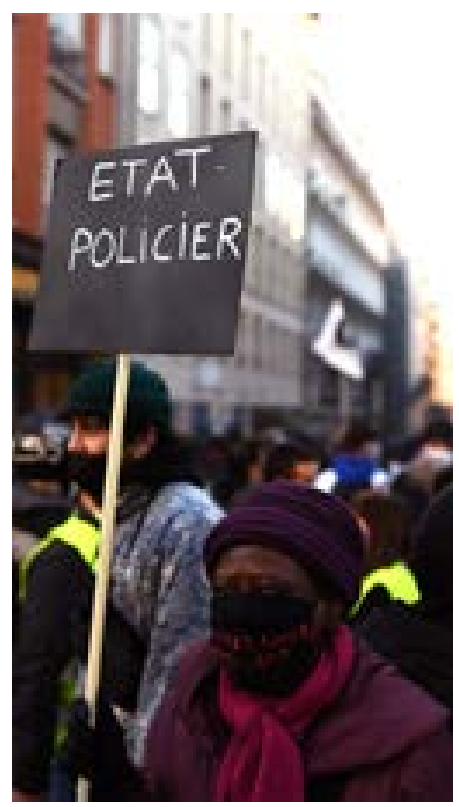

The same force that constitutes the juridical subject in terms of its acts denies the violence of the juridical capture of life: like the blow appears in the place of the structural violence it can be used to deny, the personal act appears instead of a much more complex -political, rather than juridical-interrelation of gestures and responsibilities.

The criminalisation of militantism in France (Rocher, 2020, p. 157), for instance, rests on a strategy of individuation that is centred around the figure of the casseur, the "hooligan" or "violent" demonstrator who breaks shop-windows or burns down ATMs, produced through a continuum of media representations, techniques of law enforcement, and the militarisation of police. This figure individualises "violence" as a personal act at the same time that it displaces structural violence onto acts of protest and resistance.

As the increasing use of force and recourse to measures of exception in the context of law enforcement and during recent demonstrations in France shows, techniques of individuation -from technologies of surveillance and identification to theories of subjectivity, from heterosexist discourse to racial profiling, from 
the establishment of red-zones to the figuration of violence in visual culture and the media- constitute an important element of the enforcement of the State's monopoly on violence. The inscription of violence in the field of vision through surveillance and profiling is generally a prerequisite to the violent action of the State, and it is always in the measure in which structural and systemic forms of violence disappear, that reactions to it are construed not as protest and defence, but as "violence" or as illicit, "anti-social", forms of aggression.

Surveillance and profiling further reinforce the construction of violence as a matter of violent acts that can be isolated and punished, rather than that of structural forces that operate and that can only be addressed, and destituted, collectively. A politics of nonviolence thus requires, for Butler, stepping beyond the spectacular visibility of the blow and toward an epistemology grounded on common responsibilities. Coherently, her discussion of nonviolence begins with the recognition of the primacy of structural violence and, on this basis, moves toward an "aggressive nonviolent" practice grounded in mutual dependency.

This can be compared with Agamben's own, more implicit, approach to "the blow" through an archaeology of the act as part of, on the one hand, the juridical and, more broadly, the biopolitical capture of human lives and, on the other, the critique of an instrumental, operative relation to the body. Together, Butler and Agamben's perspectives invite a reappraisal of the matter of violence and nonviolence in terms of a commonality of being -a relational interdependency for Butler, a common use of bodies for Agamben.

Both perspectives come quite close, without really speaking its name, to anarchy. This potential direction was more explicitly addressed in Weber's discussion of the monopoly on legitimate violence -even though, obviously, Weber did not walk that way. For Weber, the State-and, by extension, what he called "politics" and which we would call "government"-is characterised by the instrumental use of physical violence, to the point that:

"If there existed only societies in which violence was unknown as a means, then the concept of the 'state' would disappear; in that event what would have emerged is what, in this specific meaning of the word, we might call 'anarchy."' (Weber, 2004, p. 33)

Butler understands nonviolence precisely as an anarchic force that counters structural forms of violence: 
"[...] nonviolence has now to be understood less as a moral position adopted by individuals in relation to a field of possible action than as a social and political practice undertaken in concert, culminating in a form of resistance to systemic forms of destruction coupled with a commitment to world building that honors global interdependency of the kind that embodies ideals of economic, social, and political freedom and equality." (Butler, 2020, 2.68)

Neither simply "a practice that stops a violent act" (Ibid., 2.74) nor a form of self-defence based on personal or communitarian entitlements (Ibid., 2.57), nonviolence emerges in Butler as a potentially aggressive re-affirmation of equality and interdependency as formative conditions of life.

"If we seek to preserve each other's life, this is not only because it is in my interest to do so or because I have wagered that it will bring about better consequences for me. Rather, it is because we are already tied together in a social bond that precedes and makes possible both of our lives. My life is not altogether separable from the other life [...]" (Ibid., 2.156)

We can connect this point with Agamben's genealogical critique of the capture and separation of lives in the sphere of the law and his archaeology of the act as part of the biopolitical paradigm. What is a denied social bond in Butler is explored in Agamben's work as the very site of operation of biopower, which introduces distinctions in the sphere of gestures, separating lives from their forms, and isolates individuals through their acts, eventually consigning lives themselves to criminality (Agamben 2015, p. 119). Like the blow, the act emerges in Agamben as the threshold between structural violence and juridical individuation, commandment and nature, life and law.

In Karman, Agamben addresses how the juridical concept of culpa (guilt) originally signified a limitation of responsibility, that is, the individuation of a domain of responsibility that coincides with an isolated subject.

"This confirms the liminal value of $[$ culpa] with respect to the juridical sphere. It is not properly a juridical concept, but instead indicates the threshold across which a certain behavior becomes imputable to the subject, who is constituted as "culpable" [...] We are dealing with a fatal threshold, because it leads into a region where our actions and our gestures lose all innocence and are subjected to an alien power: punishment or pain [pena], which means both the price to be paid and a suffering for which we cannot give ourselves a reason." (Agamben, 2018, p. 6) 
Figure 6: The gesture and the act.

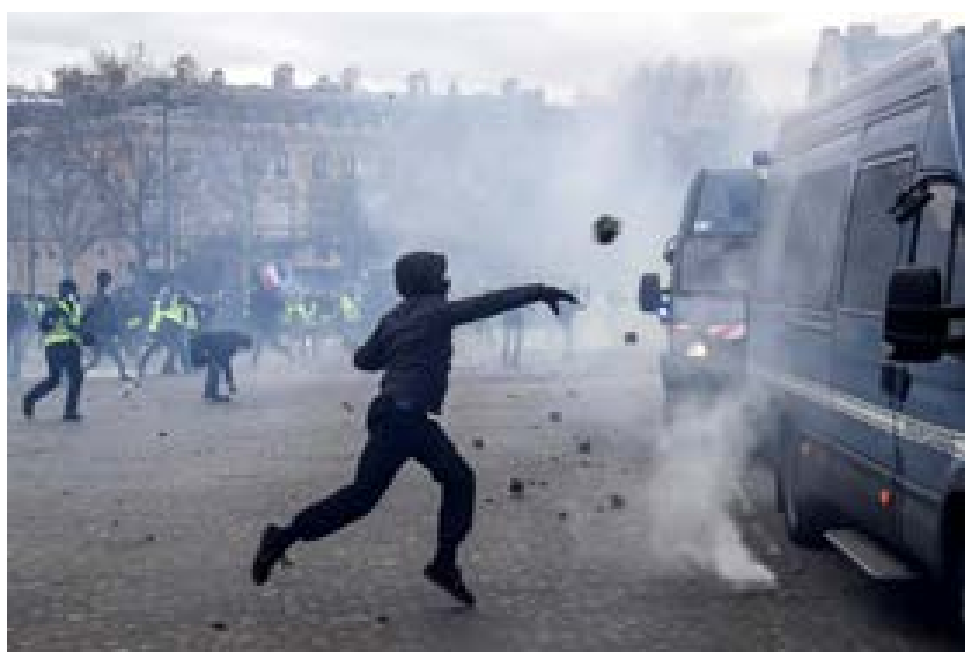

This understanding of culpa is then correlated to the idea of crimen: "action, insofar as it is sanctioned [...] the form that human action assumes when it is imputed and called into question [in causa] in the order of responsibility and law." (Ibid., p. 25). Crime is thus the name of every and any gesture insofar as it falls under the domain of the law -we can understand, then, how "the greatest crimes," as Jean Genet wrote, are "the judgements of men." (Genet, 2021, p. 68)

In the case of a person illegally crossing a border, for example, crimen would be the gesture of crossing, causa would be the notice of the crime, an intimation to stop for instance, and culpa, interestingly, would be the border itself, as that apparatus that calls the sphere of gestures (here, walking) within the order of juridically sanctionable actions.

Ethics and politics, being for Agamben a matter of gesture (in his peculiar definition of it as a means without an end, of a means that makes inoperative its relation with its original end), fall outside of the juridical/biopolitical capture of lives and rather render this very capture inoperative.

"The idea [...] of a human activity that never settles into a crimen, into a culpable and imputable act [...]. Atman ['the Self' in Vasugupta's Aphorisms of Shiva, which Agamben has referred to earlier in the book] is a dancer, and its actions are only gestures. Praxis - human life - is not a trial (an actio), but rather a mysterion in the theatrical sense of the term, made of gestures and words." (Agamben, 2018, p. 83) 
Figure 7: The Self is a dancer.

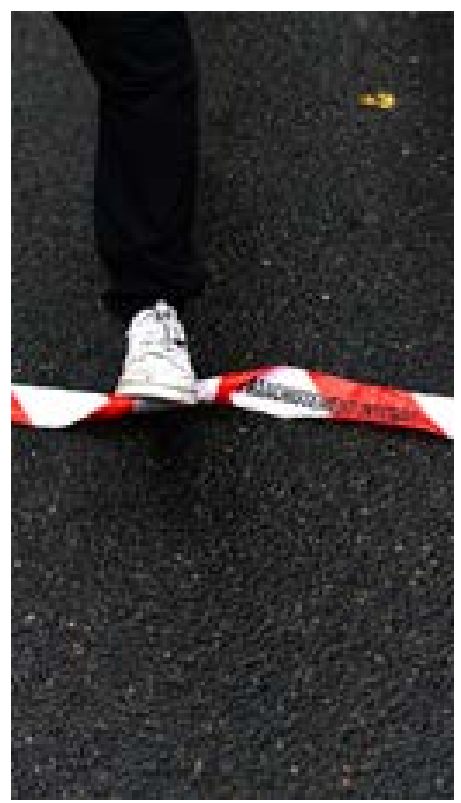

What Agamben imagines against the juridical capture of action within the sphere of the law is a mode of being that suspends the split between words and things, images and gestures, lives and forms, poetic and philosophical language, voice and logos. German Primera calls this very split "the signature of violence" (2018, p. 217). ${ }^{2}$ Here, again, we find the knot that ties police as a sensory and epistemological distribution of the sensible, like in Rancière, and police as a commandment enacted in the suffering flesh.

2 "At the core of the metaphysical machinery of the West there is violence, which is the name for the split within signification between the common and the proper - between the signified and the signifier, between philosophy and poetry - which provides the basic structure and the internal logic of all discursive formations and which represents a violent foundation of Western concepts." German Primera, "Biopolitics and Resistance: The Meaning of Violence in the Work of Giorgio Agamben" in Gavin Rae and Emma Ingala, eds. The Meanings of Violence: From Critical Theory to Biopolitics (New York: Routledge, 2018), 217. "The history of metaphysics, then, is not so much the privileging of one term (signified, phone, Being, bios) over another (signifier, gramma, beings, zoe), and the subsequent covering up of this operation, but rather, the presentation of this very differentiation as ontological." Ibid., 211. 
In relation to the previous example, the ethical and political paradigm of dance evoked by Agamben above would correspond not to the crossing of the border regardless of the legality of the action, but to the abolition of all borders. This abolition is, again in Primera's words, an "inoperative violence" (Ibid., p. 222), a nonviolent aggression that suspends the reproduction of structural violence and of the sanctioned performances that go with it.

Like Butler, Agamben refers to Benjamin's pure or divine violence in order to conceptualise this suspension as destituent power and as a move beyond the instrumental paradigm of the body:

"It is as a paradigm of 'pure mediality,' namely, one that is removed from every immediate relation with an end, that one must understand the violence that, in opposition to the violence that founds or conserves the law, Benjamin calls 'pure or divine violence,' which neither founds the law nor conserves it, but 'deposes' (entsetz) it. 'What if it were possible to discover,' he asks, 'a different kind of violence that certainly could be neither the justified or the unjustified means to those ends but was not related to them as a means at all but in some different way."' (Agamben, 2018, p. 81)

In connection with the same idea from Benjamin's "Critique of Violence", Butler also seems to invite us to move beyond a utilitarian and then an instrumental understanding of violence (Butler, 2020, 2.59). Because of its inevitable involvement in structural and systemic forms of violence, and because of the very personalistic understanding of violence that a figuration of violence in terms of the blow produces, a politics of nonviolence requires for Butler answers that go beyond the defence of violence as a means to an end both by and against constituted power, as well as beyond the idea of the body as a thing with boundaries (Ibid., 2.60). In the work of Agamben, as well, we find a critique of the instrumental paradigm of action: thinking gesture and speech (performances) beyond the instrumentalist framework that justifies violence, judgement, and hierarchies, politics and ethics emerge in Agamben as a matter of the pure gesturality -or, we could say, the inoperative performativity- of human lives:

"The 'force of law' that supports human societies, the idea of linguistic enunciations that stably obligate living beings, that can be observed and transgressed, derive from this attempt to nail down the originary performative force of the anthropogenic experience [...].” (Agamben, 2017, p. 354) 
Beyond its biopolitical capture, the body is not a thing or a property, but already a use of bodies in the plural, a matter of potentiality and destituent power. It is precisely in connection to a similar requestioning of the matter of the body that Butler will seek, in turn, a non-individualistic understanding of equality and a practice of nonviolence based on relational dependency.

\section{"The threshold of the person": Butler and Federici on violence, reproduction, and support}

Throughout her work, Butler often writes about a ground of embodied relationality that is formative of both politics and life: nobody can live without support, from other people, other animals, from the environment, so that the basis of social life is a relationality which not only pertains to interpersonal relations, but informs the body and subjectivity themselves.

The idea of embodied relationality that we find in The Force of Nonviolence is close to Butler's discussion of relational dependency with Athena Athanasiou: there, Butler evoked a "relational subject" in the terms of Arendt's idea of political actions in which the self is conceived as a plurality and thus bears an agency that is, at least in part, outside of the domain of choice and thus beyond the sphere of sovereignty and contract: "[...] we have obligations to preserve the lives of others whether or not we have contractually agreed to preserve their lives" (Butler and Athanasiou, 2013, p. 122-123). From this perspective, Butler individuates a sphere of political and ethical relationality and responsibility that exists before and beyond the constitution of the State, normative forms of life, and the sphere of legality and violence that corresponds to them.

Ethics takes shape precisely as a relationality and responsibility that grounds, but also exceeds, juridical accountability, and in this respect again Butler's and Agamben's philosophy can be brought together. An affirmation of something I have never chosen defines ethics in Butler in a way that is close to Agamben's, for whom, as he put it, ethical is the affection I receive from the relation I have with a body in which a life dwells but to which this life does not essentially belong.

"In this sense, every use is a polar gesture: on the one hand, appropriation and habit; on the other, loss and expropriation. To use - hence the semantic breadth of 
the term, which indicates both use in the strict sense and habitual praxis - means to oscillate unceasingly between a homeland and an exile: to inhabit." (Agamben, 2017, p. 1106)

Dwelling is, in Agamben, a way to name the thrownness of being beyond any form of essentialism or entitlement: the relation of the subject to the body is not given as a juridical relation of property or a disciplinary one of identification and individuation, but a use, and use entails at once acting and being acted upon, also being acted by one's acts and in that sense to dwell in them and to make oneself witness of them.

Figure 8: The execution of Pulcinella

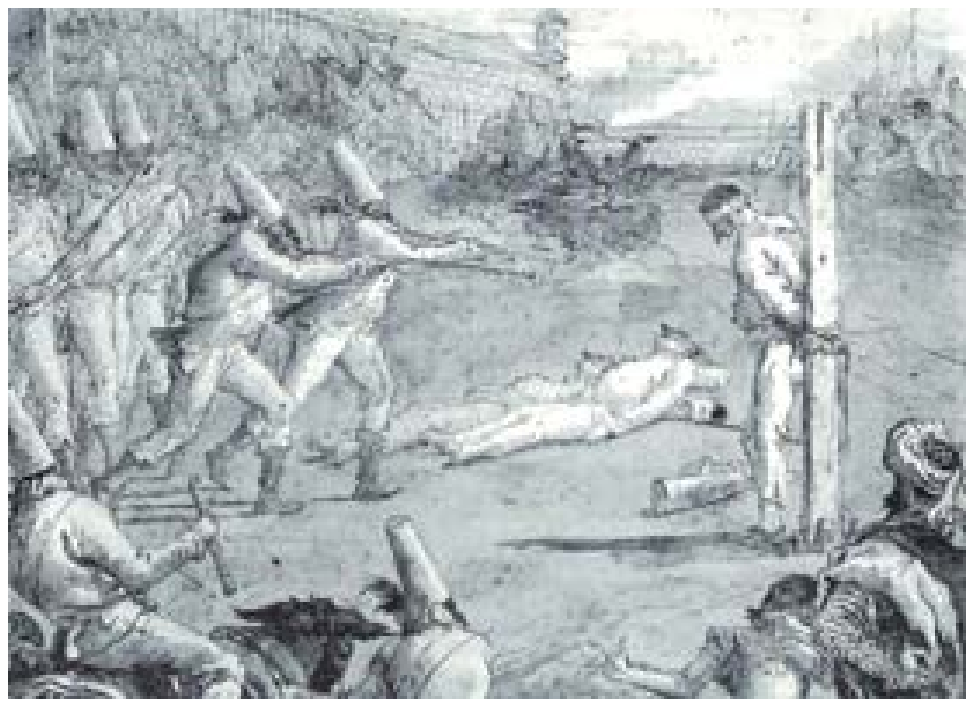

In Senses of the Subject, Butler addressed relationality and ethics as a matter of an involuntary "impingement" of things and situations on the body and the self (Butler, 2015, p. 12). On the one hand, this was an argument against a sovereign understanding of action -agency cannot be separated from the universe of relations and situations by which the body is continuously being acted upon.

"I would say that we must affirm the way we are already and still acted on in order to affirm ourselves, but self-affirmation means affirming the world without which 
the self would not be, and that means affirming what I could never choose, that is, what happens to me without my willing that precipitates my sensing and knowing the world as I do." (Ibid.)

On the other hand, it conveyed the idea that agency and the body themselves are radically supported, that they are only given, and can only express their lives and continue to exist, as part of a supportive interdependency.

"If I can come to touch and feel and sense the world, it is only because this "I," before it could be called an "I," was handled and sensed, addressed, and enlivened." (Ibid., p. 11)

For Butler in Senses of the Subject, denial of this involuntary, nonsovereign, and supportive, interdependency amounts to the destruction of "a social and relational world" (Ibid., p. 12). In a similar way, violence in The Force of Nonviolence is understood fundamentally as a violence -discursive as well as physical-against this common use that informs and supports our lives. Violence, we can say, not only forces bodies within borders, but decides the borders of the person, enclosing each of us within them.

If violence, in Butler, attacks the interrelationality and support that are formative of human lives, nonviolence, coherently, is given at once as resistance against the powers that kill and let die and as a commitment to equality beyond individualism (Butler, 2020, 2.55), that is, it takes place beyond the fictions of an autonomous and self-sustaining subject and beyond a relation to body and environment that is entirely objectual and instrumental. "Nonviolence as a matter of individual morality," Butler suggests, "thus gives way to a social philosophy of living and sustainable bonds" (Ibid., 2.62).

Taking Robinson Crusoe as the individual white male subject at the centre of an influential "phantasmatic scene" about the state of nature in the history of political philosophy, Butler argues how even the figure who is supposed to be the most independent of subjects and self-reliant of heroes -we should remember that it is Crusoe's exceptional independence and isolation that, in his view as in the providence of god, grant him rights as a sovereign- has been dependent from other human beings for his survival in its infancy.

Indeed, Butler remarks, in political fictions about the origins of society, the subject tends to be given as always-already an adult and a man, always-already separate from other beings and fully individuated and self-possessed: 
"[...] the individual who is introduced to us as the first moment of the human, the outbreak of the human onto the world, is posited as if he was never a child; as if he was never provided for, never depended upon parents or kinship relations, or upon social institutions, in order to survive and grow and (presumably) learn." (Ibid., 2.84)

The French novelist Michel Tournier, in his poetic deconstruction of Defoe's story, had not failed to catch this paradoxical aspect of Crusoe's sovereignty: in the novel, it is Robinson's mother who is described as "a sovereign woman" (une maitresse femme) and it is only in the states of abject physical prostration he spends rolling in the mud, that Crusoe, in Tournier's version, recognises being his father's son (1972, p. 41).

In the French novel, bare life appears under the lineage of the father, coherently with Agamben's understanding of the fundamental correspondence between the sovereign and homo sacer, precisely when horizontal and common networks of support fail.

"He now knew that human beings are like those who are wounded in an uprising or a riot and stay upright as long as the crowd supports them by pushing, but slide on the ground as soon as it disperses. The crowd of his brothers, who had kept him in the human without him knowing, had suddenly taken leave of him, and he felt he did not have the strength to hold himself on his own legs." (Ibid., p. 40, translation mine)

On the island in Defoe's novel, Crusoe derives his sustenance from slavery (see Federici and Fortunati, 1984, p. 282), hunting, and the instrumental exploitation of the environment, but all this would still be impossible without a more fundamental and prior reliance on relations of nurturing and support both from the environment and from the people who took care of his upbringing. Only the tools Crusoe scavenges on the shipwreck allow him to restore "civilisation" in the form of slavery and white English bread, this much he acknowledges, but those tools and his very use of them depend in turn from other lives, which he negates. The first thing Robinson does in Tournier's version is to look for his shipmates, something Defoe's Crusoe never does.

From the standpoint of political economy, what sustains Crusoe's life, even in his seemingly autarchic life on the island, is a prior support and exploitation: that of the work of reproduction (Federici, 2004, p. 8). Before the sovereign contract that establishes the modern State, and before the instrumental use of the 
environment, indeed, there are relations of care and mutual aid and dependability that are often captured within political economy precisely in the form of their exclusion.

This re-joins Silvia Federici's anticapitalist feminist questioning of the role of reproduction in capitalist relations and its disavowal in political economy. In an article from 1975 with Nicole Cox, Federici addressed housework as an essential element of the capitalist wage system, laying the base for her later, and broader understanding of reproductive work:

"Housework [...] is servicing the wage earners physically, emotionally, sexually, getting them ready for work day after day. It is taking care of our children [...]. Behind every factory, behind every school, behind every office or mine there is the hidden work of millions of women who have consumed their life, their labor, producing the labor power that works in those factories, schools, offices, or mines." (Federici, 2020, p. 27)

Under modern capitalist relations of production, women's housework was simultaneously not counted as work and fundamental to the whole structure of the exploitation of labour. Unwaged housework also shows how wage labour always includes an element of discipline and domination (see Ibid., 29-30): women were formally excluded from wages all while the capitalist system controlled their workday, and most significant aspects of their private life as well, through the institution of the patriarchal family and the husband's salary. Unwaged housework thus served for a generation of feminists as a model of this exclusive inclusion in the capitalist system of waged labour: something that has been possible, in turn, through a reflection on the institution of slavery and its central place in capitalist accumulation, with black liberation movements and the emergence of postcolonial studies, and that has been further developed, more recently, in more or less direct dialogue with the zapatistas insurrection and the zapatista communities' distinctive way of bringing together feminist, anticapitalist, and anticolonial perspectives towards a joint struggle for autonomous government and the defence of life (see Ibid., p. 78). ${ }^{3}$

3 Federici's argument is, for example, that the destruction of communal forms of agriculture creates a precarity and dependency that are essential to the imposition of capitalist relations of production; this, both in the history of capitalism and in contemporary neo-colonial practices pursued, among other institutions, by the International Monetary Fund. 
Figure 9: Unconquered.

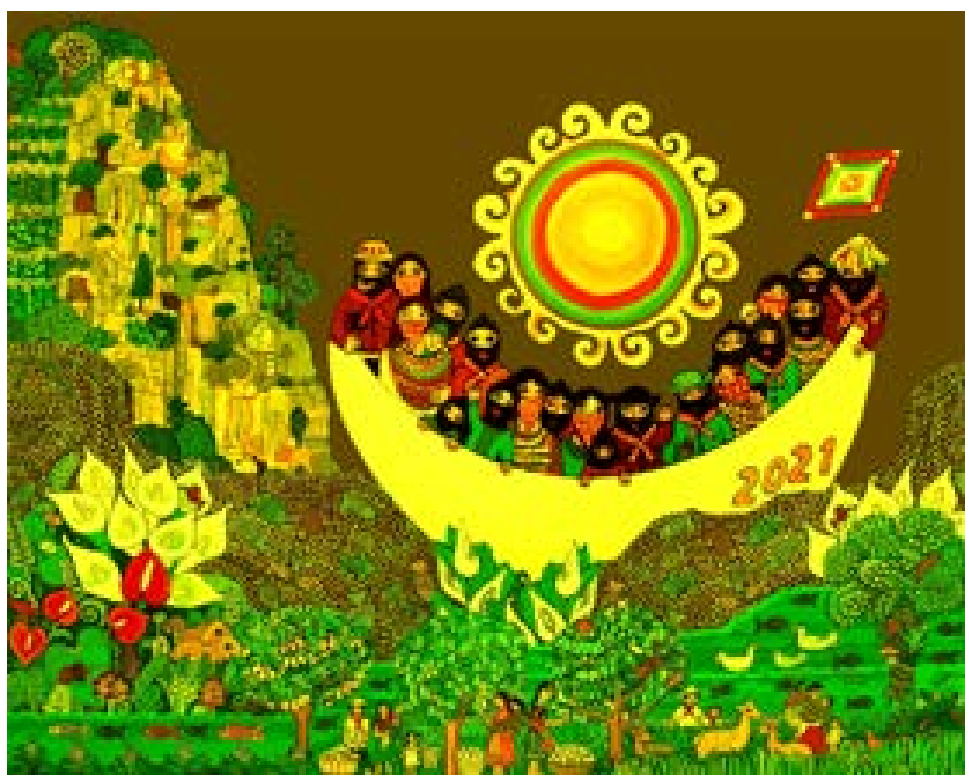

Broadly intended, reproduction work is the work needed to reproduce and sustain our lives and the commons on which our lives depend. Feminist struggle, which for Federici entails "reclaiming the means of our reproduction - the lands, the waters, the production of goods and knowledge, and our decision-making power, our capacity to decide what kind of lives we want and what kind of human beings we want to be" (Federici, 2020b, p. 30), can thus be understood as a form of aggressive nonviolence defending gestural commons, on the lines of Butler and Agamben.

If, in Dorlin, the slave is defined by being denied the right to self-defence and self-preservation (2019, p. 29), self-defence should be reinvented beyond the question of the legitimacy or illegitimacy of the recourse to violence, and instead as the matter of the preservation of a common, gestural rather than instrumental, use of bodies.

This contrast of ethical and political modes of relation to the body -the instrumental and the communal- are discussed in Agamben's The Use of Bodies in relation to ancient slavery, in which the use of the body "defines a zone of indifference between one's own body and the body of another," in relation to the 
ideas of "care-of-oneself" and "self-dispossession" in Foucault, in which the use of the body emerges indistinguishably in terms of agency and being acted upon, and finally in relation to the question of technology in Heidegger, in which "a constitutive connection between slavery and technology" appears, precisely in the terms of an instrumental use of the body (Agamben, 2017, pp. 1047, 1038$1039,1099)$. All these three aspects of Agamben's idea of use relate to a politics of everyday gestures and to the question of destituent power discussed above.

We can note the implications that Butler's argument about the interrelationality that supports embodiment has in relation to the idea of agency, connecting it to what Ferdinand Deligny suggested about subjectivity in an essay from The Arachnean, distinguishing the juridical and philosophical individual (individu) from the meshwork of gestures, emotions, words and situations, which every subjectivity is made of and which Deligny called the indivisible (individuel). From this perspective, everything we think or do is radically supported, a gesture too is not something with boundaries. The very sense that it is possible to act is found together, in the ways people depend on and encounter each other. This is what it means to think about human lives in terms of their gesturality in Agamben, as this meshwork of gestures bears a potentiality that is communicated as such and that can never be exhausted in act.

Separation appeared in Weber's essay on the monopoly of legitimate violence as part of the formation of the apparatus of state officials (Weber, 2004, pp. 37-38). Debord will later return to this idea, and will generalise this "official" separation -an instrumental and purely performative relation to power- to the lives of all citizens. Both Debord and Agamben understand this separation to be fundamentally religious: a matter of materialised semblance for Debord -the spectacle as "the material reconstruction of the religious illusion" (Debord, 2014, p. 6); a more fundamental matter of sacralisation -of the relegation to a separate sphere- for Agamben. In this sense, for the latter, politics and ethics begin with a profanation, that is, with the restitution to the common of what has been subjected to separation.

What Butler and Athanasiou discuss in terms of dispossession and what Federici analyses as a continuing process of primitive accumulation leading to the enclosure of more and more aspects and domains of people's lives, can thus further be linked with this critical genealogy, including Weber, Debord and Agamben, that addresses separation and individuation as the fundamental epistemological and disciplinary apparatus of state power and capitalist accumulation. The common gesturality of human lives, which Butler and Federici describe in terms 
of relational interdependency and reproductive commons, and that Agamben refers to as a common use of the body, is the point where the apparatus of capitalist biopower and that of State individuation intersect and where their power to capture and construct human bodies as things with purposes and borders meets the potentiality and the gestural commons: the lives, to put it simply, that can depose them.

\section{Conclusion: State terror and Defacing}

In the prologue to Se Défendre, Elsa Dorlin evokes a torture in which the very attempts of the victim -Millet de la Girardière, a slave- to save himself and avoid pain are causing him even more pain and are painfully driving him to his own death. With this scene, Dorlin provides a necessary complement to the Foucauldian theory of discipline, showing not only how systems of power include resistance in their own mechanisms, but also how the capture of self-preserving and life-affirming forces by disciplinary institutions does not exclude the recourse to the infliction of pain and the spectacular destruction of bodies.

\footnotetext{
"Repressive authority is no longer obliged to cast the powers that oppose it as absolutely impotent in order to affirm itself. On the contrary, the more this subjective power stages its repeated and desperate efforts to survive, the more repressive authority succeeds in governing it [...]. This deadly government of the body is carried out with such an economy of means that the condemned appears to perish by his own hand alone." (Dorlin, 2019)
}

What appears here is a vulnerabilisation, an injury, a death, and a spectacle of all of these together, that take place through the very resistance that the body opposes to its own destruction, through the inescapable reflexes by which the subject attempts to escape pain, and through the very gestures one makes against the power structure in which one is caught.

Where Butler addressed vulnerability in resistance as a nonviolent strategy of defiance (Butler, 2016, p. 14), here we see a power that takes the spectacle of agony and powerlessness as its own right and pleasure -jouissance, in the proper Sadean sense: a spectacle, in domestic law enforcement and war abroad, that constitutes the State's emblem and glory (Agamben, 2017, pp. 75-76). 


\begin{abstract}
"Here we see how an apparatus of domination can set out to persecute the very movement of life, targeting its vital impulse in its most muscular forms. The slightest gesture of defence or protection, the slightest movement aimed at the preservation and conservation of the self is enlisted in the annihilation as such of the body." (Dorlin, 2019)
\end{abstract}

With the intensification of biopolitical techniques, with the enclosure of more and more aspects of our lives and their capture within capitalist relations of production and reproduction, as well as with the exacerbation of an operative split between lives and their forms, we witness a power that, like a scalpel or a bullet, is applied at the interface between technics and the speechless body. Government addresses a body that it reduces to reflexes and vulnerabilities: whatever identity the State recognises is predicated on a more radical negation of communal and embodied existence.

Figure 10: Pedro Fidalgo, La violence ne fera pas taire le peuple, 2019.

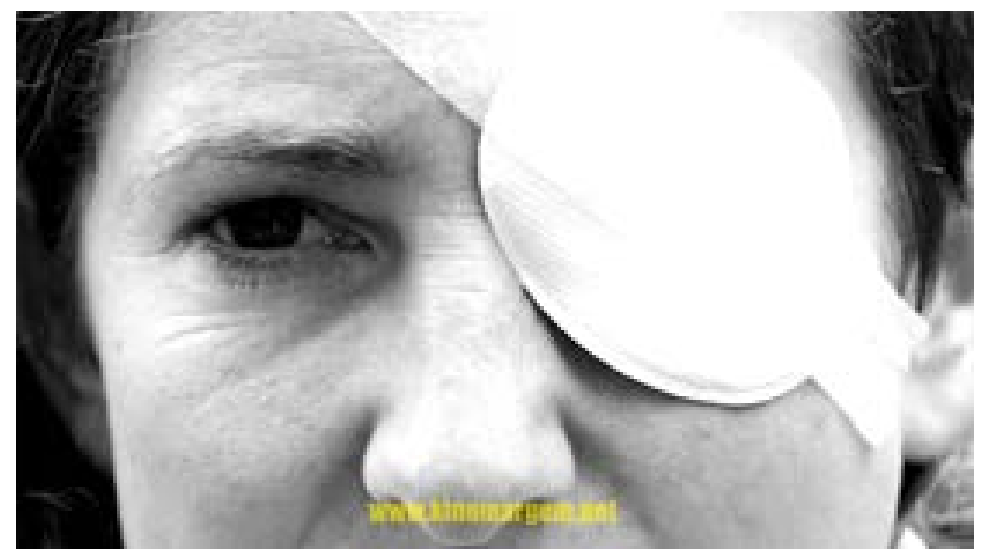

"Prior to any particular expression and beneath all particular expressions, which cover over and protect with an immediately adopted face or countenance, there is the nakedness and destitution of the expression as such, that is to say extreme exposure, defencelessness, vulnerability itself. This extreme exposure - prior to any human aim - is like a shot 'at point blank range'." (Levinas, 1989, p. 83)

For Emmanuel Levinas, the face is the ethical figure of encounter. In "Ethics as First Philosophy," in particular, the idea of the face comes to replace a relation 
to others and to the world that is first of all objectual (Ibid., pp. 84-85), in which beings exist first as things, and can be known as such, and only then as subjects, and in which existence is defined on the basis of ontology rather than ethics. The face, with its call for responsiveness and its vulnerability, stands as a mode of relation to the world that is opposite to the violent and the instrumental.

"The face, still a thing among things, breaks through the form that nevertheless delimits it. This means concretely: the face speaks to me and thereby invites me to a relation incommensurate with a power exercised, be it enjoyment or knowledge" (Levinas, 1979, p. 198) - or, indeed, violence.

In his works, anthropologist Philippe Descola relates of cosmologies others than the Western, in which other forms of life -the animal, the vegetal- are addressed in dialogue, talked to in human terms, not dealt with as objects, resources, or instruments (Descola, 2013, pp. 16.17). In the opposite way, from this perspective, the power Robinson Crusoe exerts on his island and which, as we have seen, denies the very gestural commons that it exploits, is one of unnaming and de-facing, a power to treat lives as faceless and nameless, and thus to be able to act towards them, and even name them, instrumentally (as it is done to Friday, whose name is never to be known).

In everyday life, it is easy enough to see how one can say one knows another only after having talked and spent a significant amount of time together, so that knowledge is not something else than an aspect of the sharing of life. This modality of knowledge is not available to power. Power uses violence to impose a mode of knowledge and government that is independent from, and thus opposed to, the ethical encounter: in this sense, power attempts to de-face the world.

At times, State power attempts to do this literally: the independent journalist David Dufresne has documented over 2,000 wounded, 5 mutilated hands, 27 blindings, and 2 deaths of protesters by the police during the Gilet Jaunes protests in between November 2018 and February 2020.

The systematic, and so far, unpunished, employment of mutilation in the context of the repression of the Gilets Jaunes movement by the French State has its precedents in the strategy of terror and the counterinsurgency techniques the French military experimented in Indochina and Algeria. For decades now, these strategies and techniques have been empowered, normalised, rationalised and extended to growing segments of the population, to the point that they can present themselves under the guise of normality. The banalisation of police 
violence and the discourses that justify it that we have encountered in Zootopia at the beginning of the article are part of this broader apparatus of normalisation of State violence, which reappears globally in various forms, following and enforcing the unequal distribution of the value and disposability of lives which defines securitarian capitalism.

Still, as in the beautiful shot in Pedro Fidalgo's trio of short videos, La violence ne fera pas taire le peuple [Violence Won't Bring the People to Silence] (figure 10), the wounded face keeps looking back, and people are still able to speak against the silence of power.

The face looks at the camera, at the man behind the camera, at the people watching the screen, as it looked at the one who pulled the trigger and, beyond the gun, at the many whose words and actions, spoken and unspoken, avowed and disavowed, have also pulled the trigger. It looks at them and speaks, calling all of them in the domain of politics.

\section{Sources}

Le Monde (8 March 2019). "'Gilets jaunes' : pas de 'violences policières', selon Emmanuel Macron." Source: https://www.lemonde.fr/societe/article/2019/03/08/giletsjaunes-pas-de-violences-policieres-selon-emmanuel-macron_5433154_3224.html

Agamben, G. (1998). Homo Sacer: Sovereign Power and Bare Life. Stanford: Stanford University Press.

Agamben, G. (2015). Pulcinella: Ovvero Divertimento Per li Regazzi - in Quattro Scene. Roma: Nottetempo.

Agamben, G. (2017). Homo Sacer: The Omnibus. Stanford: Stanford University Press.

Agamben, G. (2018). Karman: A Brief Treatise on Action, Guilt, and Gesture. Stanford: Stanford University Press.

Butler, J. (1993). Bodies that Matter: On the Discursive Limits of "Sex". London: Routledge. Butler, J. (2020). The Force of Nonviolence: A Ethico-Political Bind. London: Verso.

Butler, J., and Athanasiou, A. (2013). Dispossession: The Performative in the Political. Cambridge: Polity Press.

Butler, J., Gambetti, Z., and Sabsay, L., (Eds.) (2016) Vulnerability in Resistance. Durham: Duke University Press.

Debord, G. (2014). The Society of the Spectacle, translated by Ken Knabb. Bureau of Public Secrets.

Dorlin, E. (2019). Se Défendre : Une philosophie de la violence. Paris : La Découverte.

Fanon, F. (1963). The Wretched of the Earth. New York: Grove Press.

Faraci, D. (2016). "ZOOTOPIA Review: A Muddled Mess of Racial Messaging... And Cute Animals: Disney's most Dreamworksian movie has a lot to say." Birth.Movies.Death, 
6 May 2016. Source: https://birthmoviesdeath.com/2016/03/03/zootopia-reviewa-muddled-mess-of-racial-messaging...-and-cute-animals

Federici, S. (2004). Caliban and the Witch. New York: Autonomedia.

Federici, S. (2020). "Counterplanning from the Kitchen." In Revolution at Point Zero: Housework, Reproduction, and Feminist Struggle. Oakland: PM Press.

Federici, S. (2020b). Beyond the Periphery of the Skin: Rethinking, Remaking, and Reclaiming the Body in Contemporary Capitalism. Oakland: PM Press.

Federici, S., and Fortunati, L. (1984). Il Grande Calibano: Storia del Corpo Sociale Ribelle nella Prima Fase del Capitale. Milano: Franco Angeli.

Genet, J. (2021). Miracle de la Rose. Paris: Gallimard.

Hobbes, T. (2017). Three-Text Edition of Thomas Hobbes's Political Theory: The Elements of Law, De Cive and Leviathan. Cambridge: Cambridge University Press.

Levinas, E. (1979). Totality and Infinity: An Essay on Exteriority. The Hague: Martinus Nijhoff.

Levinas, E. (1989). The Levinas Reader, edited by Seán Hand. Oxford: Basil Blackwell.

Primera, G. (2018). "Biopolitics and Resistance: The Meaning of Violence in the Work of Giorgio Agamben." In Rae, G., and Ingala, E. (Eds.) The Meanings of Violence: From Critical Theory to Biopolitics. New York: Routledge (pp. 209-228).

Rancière, J. (1999). Disagreement: Politics and Philosophy. Minneapolis: University of Minnesota Press.

Rigouste, M. (2011). L'Ennemi Intérieur : La Généalogie Coloniale et Militaire de l'Ordre Sécuritaire dans la France Contemporaine. Paris: La Découverte.

Rocher, P. (2020). Gazer, Mutiler, Soumettre: Politique de l'Arme non Létale. Paris: La Fabrique.

Weber, M. (2004). "Politics as Vocation." In Owen, D., and Strong, T. B. (Eds.) Max Weber: The Vocation Lectures. Indianapolis: Hackett.

\section{Figures}

Heading. "Different branches of the Italian forces of repression together during the demonstrations, with tear gas and live ammunition at the ready." Source: Crimethinc, https://crimethinc.com/2021/07/20/genoa-2001-memories-from-the-front-linestaking-on-the-g8-at-the-climax-of-a-movement

Figures 1 and 2. Zootopia, directed by Byron Howard and Rich Moore, USA 2016.

Figure 3. Photo: Emmanuel Brossier. Rennes 29 November 2020: Rassemblement Contre le \#PPLSecuriteGlobale. Taranis News, https://taranis.news/2020/11/rennesrassemblement-contre-le-pplsecuriteglobale/

Figure 4. Copyright: Renaud Vilafranca / publihebdos. Mantes-la-Jolie, 6 December 2018. In Un Pays Qui Se Tient Sage, directed by David Dufresne, France 2020.

Figure 5. Photo: Geoffroy Van Der Hasselt, Agence France Presse, 16 March 2019. "A Paris pendant le dix-huitième samedi de mobilisation des 'gilets jaunes'." France Culture, "Flics et Casseurs," https://www.franceculture.fr/emissions/les-pieds-surterre/flics-et-casseurs-0

Figure 6. Sonia Kronlund. "Flics et casseurs", Les Pieds sur Terre. France Culture 21 March 2019. https://www.franceculture.fr/emissions/les-pieds-sur-terre/flics-etcasseurs-0 
Faceless Violence and the Gestural Commons: The Ethics and Politics of Destitution and Support in Butler, Agamben, and Federici

Figure 7. Photo: Ulysse Logéat, Paris 12 December 2020, \#PPLSecuriteglobale: Manifestation. Taranis News, https://taranis.news/2020/12/gallery-paris-12-12-2020-pplsecuriteglobale-manifestation/

Figure 8. Giandomenico Tiepolo, Il Plotone d'Esecuzione, 1797-1804. London: Private Collection. Image source: Arianna Paragallo, "Il Pulcinella di Giandomenico Tiepolo alla luce della critica del Novecento." https://www.bta.it/txt/a0/08/bta00839.html

Figure 9. Graphic for the Viaje por la Vida, 2021. https://viajezapatista.eu/en/

Figure 10. Cinema-Oeil (Kino-Glaz), directed by Pedro Fidalgo. Part two of La Violence Ne Fera Pas Taire Le Peuple. France, 2019. https://en.kinomargem.net/la-violencene-fera-pas-taire-le-pe 